\title{
The efficiency of application urea with urease inhibitor to increase potato yield
}

\author{
Maria Vizirskaya ${ }^{1}$, Anna Shchepeleva ${ }^{2}$, Natalia Akanova ${ }^{1}$, Vasilii Zhdanov ${ }^{3}$, and \\ Sergey Sherstobitov ${ }^{4}$ \\ ${ }^{1}$ All-Russian Research Institute of Agricultural Chemistry named after D.N. Pryanishnikova, \\ Pryaniishnikova st, 31, 127550 Moscow, Russia \\ ${ }^{2}$ Peoples Friendship University of Russia (RUDN University), Miklukho-Maklaya str.6, \\ 117198 Moscow, Russia \\ ${ }^{3}$ Moscow Aviation Institute, Volokolamskoe Shosse 4, 125993 Moscow, Russia \\ ${ }^{4}$ Governmental Agrarian University of Northern Ural, Respubliki st. 7, 625003 Tumen, \\ Russia
}

\begin{abstract}
In the article are presented the investigation results, which shows the effectiveness of urea with urease inhibitor - nBPT in potato growing agroecosystems. The advantages of the new fertilizer are the yield increase, and quality improvement. Urea with nBPT lead to formation bigger tuber size what is one of the most important characteristic for marketable potato. Fertilizer was tested in experimental fields and in real farm conditions.
\end{abstract}

\section{Introduction}

Nitrogen is one of the most essential elements in plant nutrition. Fertilities are the main sources of it. The most common are urea and ammonium nitrate. Nitrogen assimilation of this element by plant root system occurs in the form of nitrate ion or ammonium ion [1]. The transformation of nitrogen fertilizers in the soil is accompanied by the loss of nutrients, which significantly reduces the efficiency of nitrogen assimilation by plants. In addition, nitrogen losses in various forms - in gaseous forms (ammonia, nitrogen oxides) or as a result of leaching processes (nitrates) - have a negative impact on the environment, polluting air and water resources. All this processes leads to the deterioration of plants nutrition, and also to environmental $[2,3]$.

After application to the soil, the urea is hydrolyzed to ammonium nitrogen, thanks to the urease enzyme in the soil, the next process is ammonia oxidation to nitrite (intermediate) and then to nitrate. In the course of these processes nitrogen losses

\footnotetext{
* Corresponding author: Mvizir@gmail.com
} 
depending on soil and climatic factors can amount: $20-60 \%$ in form of NH3, 2-4\% in $\mathrm{N} 2 \mathrm{O}$ form, $20-40 \%$ in NO form, and up to $60 \%$ in NO3 form [4].

Currently, fertilizers almost for all agricultural crops in Russia are applied fractionally (basal application, broadcasting, pre- and before- sowing application, topdressing). This makes it possible to provide the necessary level of nutrition to plants during the vegetation period and reduce the anthropogenic preassure on the environment, but the cost for the use of fertilizers increases.

Urea is one of the most applied in the world nitrogen fertilizer, which accounts for about $55 \%$ of the total world nitrogen fertilizers consumption [5]. And the most important problem associated with application of this product is nitrogen losses due to action of enzyme urease [1]. All over the world are applied about $105 \mathrm{Mt}$ of $\mathrm{N}$ fertilizers and approximately $37 \mathrm{Mt}$ of $\mathrm{N}$ are lost per year.

Urea applied to soils undergoes fast hydrolysis, producing ammonia (NH3), which can be lost to the atmosphere. Ammonia losses can be both an economic and an environmental problem.

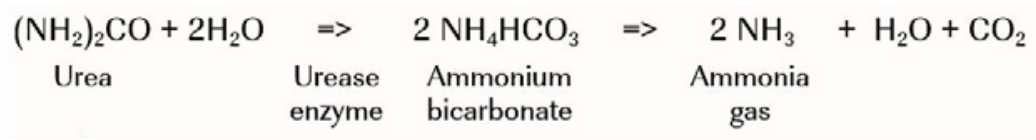

Fig. 1. Urea transformation in soil

The urease enzyme transform the urea molecule into ammonium bicarbonate $-\mathrm{a}$ highly unstable compound that decays to free ammonia form, which is released to the atmosphere (Fig. 1). It should be noted that ammonia released from the fertilizer remains in the soil for a long time, preventing the formation of nitrate nitrogen and is toxic to young seedlings $[1,4,6]$.

There are many factors affecting the urea transformation processes.

The amounts of $\mathrm{N}$ lost as NH3 vary with soil and environmental conditions, the losses are higher when:

- urea is surface-applied to light soils (due to low cation exchange capacity),

- with high temperatures and moisture content [2,7,8],

- and high $\mathrm{N}$ rates (As an example - band application usually results in higher losses than broadcasting fertilizer because of the high $\mathrm{N}$ rate effect $[9,2]$.

Incorporation of urea into the soil is an effective way of reducing or even preventing NH3 volatilization losses. This can be done by mechanical operations or by irrigation (naturally by rain). There are researches, which show that application of approximately $15 \mathrm{~mm}$ of water soon after urea fertilization was enough to incorporate the fertilizer into the soil and reduce NH3 losses by $90 \%[10,11]$.

Mechanical incorporation can reduce losses, but the depths should be greater than $7.5 \mathrm{~cm}$ to prevent NH3 volatilization [12,13]. Urea incorporation is, therefore, part of the best management practices for increasing nutrient use efficiency from urea. However, incorporation is not always possible. For perennial crops it can cause mechanical damage to the root system, for no-till areas it is impossible to incorporate fertilizers. Mechanical incorporation require higher-power tractors and is timeconsuming, so it becomes very expensive practice. Therefore, in Russia much more common is ammonium nitrate application. This fertilizer contain less $\mathrm{N}$, but there is no need of immediate incorporation to save $\mathrm{N}$ and prevent volatilization $[14,15]$.

But ammonium nitrate is not the best solution. There is a risk of losses as well because of high mobility of nitrate and possibility of denitrification (volatilization in 
forms of nitrogen oxide). Moreover, ammonium nitrate faces increasing restrictions because of its explosive properties.

To solve this problem, it is possible to use high-efficiency fertilizers - urea containing inhibitors that allow to prevent losses and apply fertilizers once during the growing season, or at least to reduce the frequency of application.

The most popular and widely applied in the world is N-(n-Butyl) thiophosphoric triamide (NBTPT or NBPT), which converts to active N-(n-Butyl) phosphoric triamide (NBPTO or BNPO) $[10,15,16]$.

Urease inhibitors, as additives to fertilizers, block the activity of the urease enzyme secreted by urobacteria in the zone of contact of fertilizer with the soil solution [5]. As the results we prolongate period of urea transformation to NH3 what helps to decrease losses and save more available nitrogen for plants.

Liquid urease inhibitor is uniformly sprayed to granulated urea, inhibitor lead to extension of nutrients availability period for plants, creates favorable conditions for seed germination and the start of vegetation, reduces the phytotoxic effect of fertilizers on the plant. Compared to conventional urea, nBPT protects the fertilizer from the action of urease during hydrolysis after its application to the soil, which provides the delay of the transformation of amide nitrogen into ammonia for 10-15 days [9, 7]. This contributes to the losses reduction of nitrogen in form of ammonia up to $60 \%$ compared to losses from conventional urea, even compared to the incorporation it into the soil $[6,10]$.

To assess the efficiency of urea with nBPT in 2017 were carried out field trials: potatoes trial was organized in the Volgograd region in the experimental polygon of the Nigne-Volgskiy agricultural research Institute - branch of "Federal scientific center of agro-ecology, integrated land reclamation and protective afforestation".

The relevance of the research topic is to propose innovative technology and an effective instrument to reduce nitrogen losses, and to increase nitrogen use efficiency using the test object - potato-growing system.

This research aims are to study and evaluate the effectiveness of inhibited urea in the potatoes cultivation system, and to develop recommendation for inhibited urea application in potato mineral nutrition system.

\section{Materials and Methods}

In order to assess the effectiveness of urea with nBPT the field trial was carried out in 2017 in condition of Volgograd region. Trial plots were characterized by alkali light brown soil with high clay content.

The agrochemical characteristics of the soil are the following:

humus content of $2.27 \%$ (according to Tyurin, GOST 26213-91, method based on oxidation of organic matter with a solution of potassium bicarbonate in sulfuric acid and the subsequent determination of trivalent chromium, equivalent to the content of organic matter, on a photoelectrocolorimeter),

soil $\mathrm{pH}$ (H2O extraction) - 7,49,

mobile P2O5 content - 8,82 mg/100 g (GOST 26205-91, extraction by ammonium carbonate)

exchangeable K2O - 40,43 mg/100 g (GOST 26205-91, extraction by ammonium carbonate). 
The vegetation period in Volgograd region was atypical and unfavorable for vegetable crops. From April to May there was only $80.1 \mathrm{~mm}$ of precipitation. As a result, planting of potatoes was postponed to a later date.

As an object of research was used potatoes mid-early table varieties Nevsky. The variety is environmentally plastic, adapted to different agro-climatic condition, resistant to drought and short-term waterlogging, has high resistance to late blight, scab, black stalk and other fungal diseases. According to the methodology of phenological observations: if at least $10 \%$ of plants in the plots entered the defined phase of development, then this day was considered for the beginning of its onset. When the phase was observed for $>75 \%$ plants it was considered as mass onset the phase of development.

The trial design for the potatoes consisted of 4 treatments:

1. Control (without fertilizers),

2. Urea - $195 \mathrm{~kg} / \mathrm{ha}$,

3. Urea with nBPT $-195 \mathrm{~kg} / \mathrm{ha}$,

4. Ammonium nitrate $-262 \mathrm{~kg} / \mathrm{ha}$.

Fertilizers were placed to a depth of $8-10 \mathrm{~cm}$, in the ridges. The area of the experimental plots was $1800 \mathrm{sq}$. $\mathrm{m}$. (4.5 m x $400 \mathrm{~m})$. The experiment was carried out in 4 replications.

\section{Results and discussion}

The application of different forms of nitrogen fertilizers did not affect the duration of the phenological phases of potato development, in all the experiments the vegetation period was 90 days from the germination period.

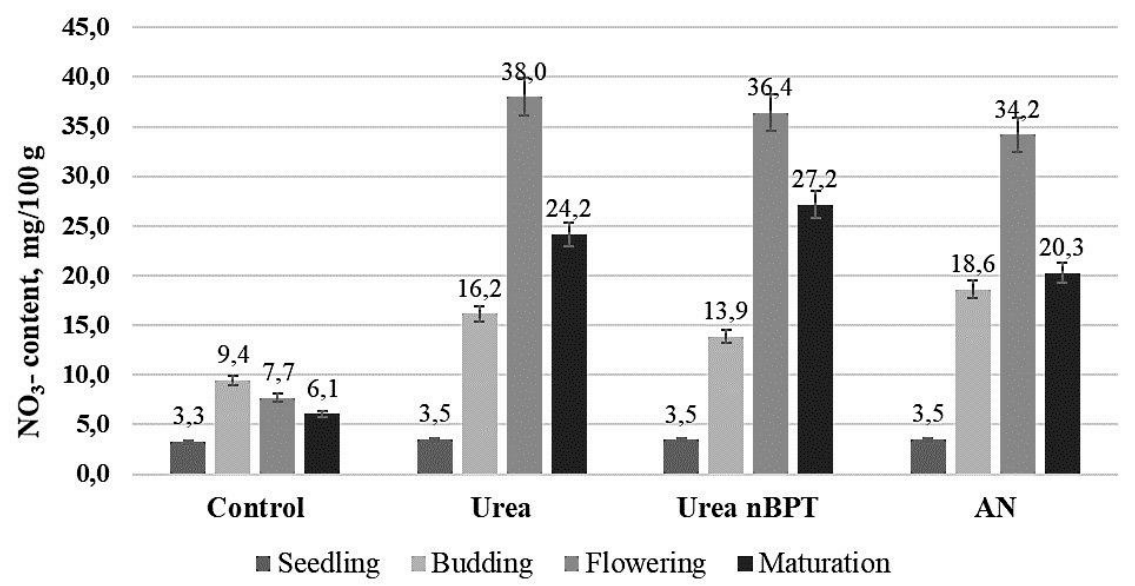

Fig. 2. Dynamics of nitrate nitrogen content in soil during application different forms of nitrogen fertilizers

The obtained data shown (Fig.2) that the form of nitrogen fertilizers had a significant impact on the content of nitrate nitrogen in the soil: the highest content in the initial periods of development was observed for conventional urea (treatment 2) and ammonium nitrate (treatment 4), the lowest - in the treatment where was applied 
urea with nBPT inhibitor (treatment 3). However, due to application full required fertilizes dosage there was no nitrogen deficiency in the soil.

It should be noted that the phase of flowering is characterized by decrease of nitrate nitrogen content in the treatment with application of ammonium nitrate. However, for the treatments with urea application nitrate nitrogen content increased. By the end of potato vegetation on the control plant the content of nitrate nitrogen was $6.07 \mathrm{mg} / 100 \mathrm{~g}$, on variants with urea application the highest was $24.16-27.17 \mathrm{mg} / 100$ $\mathrm{g}$, significantly lower when ammonium nitrate was applied- $20.27 \mathrm{mg} / 100 \mathrm{~g}$ of soil.

The results of the chemical analysis of the aboveground part of the plants shown that the prolonged action of inhibited urea provided a greater accumulation of nitrogen in the tops $-4.46 \mathrm{mg} / \mathrm{kg}$. For the treatment with ammonium nitrate application, the nitrogen content was $3.1 \mathrm{mg} / \mathrm{kg}$ (Figure 3 ).

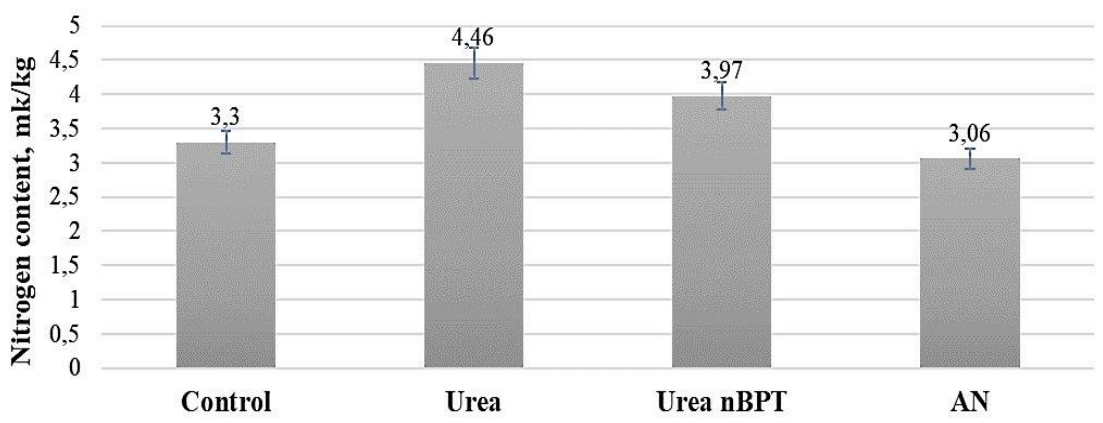

Fig. 3. The nitrogen Content in the aboveground part of the potato in the flowering phase, $\mathrm{mg} / \mathrm{kg}$

The application of urea in potato nutrition had a positive impact on the productivity formation. The lowest weight of the plant - $301 \mathrm{~g} /$ plant in the budding phase was noted in the control treatment (without fertilizers). Urea application had some advantages over ammonium nitrate; the weight of the tops in this phase was 401 $\mathrm{g} /$ plant. The highest weight of top plant part was noted in the treatment with application of inhibited urea (treatment 4) - $463 \mathrm{~g} /$ plant (table 1).

Table 1. Biometric indicators of potato plants on different growing phases

\begin{tabular}{|l|c|c|c|c|c|}
\hline \multirow{2}{*}{$\begin{array}{l}\text { Growing } \\
\text { phases }\end{array}$} & \multirow{2}{*}{$\begin{array}{c}\text { Plant length, } \\
\text { cm }\end{array}$} & \multicolumn{2}{c|}{ Quantity, unit/plant. } & \multicolumn{2}{c|}{ Weight, g/plant. } \\
\cline { 3 - 6 } & & stem & tuber & top & tuber \\
\hline \multicolumn{7}{|c|}{ 1 treatment - Control (without fertilizers) } \\
\hline Germination & 17,6 & 4 & - & - & - \\
\hline Stem formation & 28,0 & 4 & - & - & - \\
\hline Budding & 38,8 & 5 & & 301 & \\
\hline Flowering & 46,0 & 6 & 15 & 426 & 520 \\
\hline End of flowering & 53,4 & 6 & 17 & 438 & 501 \\
\hline \multicolumn{7}{|c|}{$\mathbf{2}$ treatment - Urea } \\
\hline Germination & 13,7 & 5 & - & - & - \\
\hline Stem formation & 36,8 & 5 & - & - & - \\
\hline Budding & 47,6 & 6 & & 412 & \\
\hline Flowering & 53,1 & 7 & 18 & 529 & 548 \\
\hline End of flowering & 68,0 & 7 & 20 & 551 & 634 \\
\hline
\end{tabular}




\begin{tabular}{|l|l|l|l|l|l|}
\hline \multicolumn{7}{|c|}{ 3 treatment - Urea with nBPT } \\
\hline Germination & 17,8 & 5 & - & - & - \\
\hline Stem formation & 40,6 & 6 & - & - & - \\
\hline Budding & 55,4 & 7 & & 463 & \\
\hline Flowering & 57,0 & 7 & 21 & 557 & 589 \\
\hline End of flowering & 65,8 & 7 & 23 & 614 & 662 \\
\hline \multicolumn{7}{|c|}{ 4 treatment -Ammonium nitrate } \\
\hline Germination & 17,0 & 4 & - & - & - \\
\hline Stem formation & 39,5 & 4 & - & - & - \\
\hline Budding & 48,5 & 5 & & 401 & \\
\hline Flowering & 55,9 & 5 & 19 & 512 & 522 \\
\hline End of flowering & 61,7 & 8 & 19 & 514 & 628 \\
\hline
\end{tabular}

During the end of the flowering period, the weight of the tops in the variant with the use of urea with nBPT was higher than in the treatment with ammonium nitrate by $100 \mathrm{~g} /$ Bush or $19.5 \%$, and the weight of tubers by $34 \mathrm{~g} / \mathrm{Bush}$ or $5.5 \%$. In comparison with the control, the increase of the analyzed indicators was by $40.2 \%$ and $32.1 \%$, respectively. Comparing the results with the control treatment (without fertilizers), it can be noted that the number of stems when nitrogen fertilizers was applied increases from 4 to 8 , while the form of fertilizer did not have any significant impact.

The differences of plant biomass formation caused yield differences (table 2).

Table 2. The potato productivity formation

\begin{tabular}{|c|c|c|c|c|c|}
\hline \multirow{3}{*}{ Treatments } & \multirow{3}{*}{ Yield, $t / h a$} & \multicolumn{2}{|c|}{$\begin{array}{c}\text { Addition } \\
\text { yield }\end{array}$} & \multirow{2}{*}{ Marketable potato } & \multirow{2}{*}{$\begin{array}{l}\text { Other } \\
\text { fraction }\end{array}$} \\
\hline & & \multirow{2}{*}{$\%$} & \multirow{2}{*}{ t/ha } & & \\
\hline & & & & \multicolumn{2}{|l|}{ t/ha } \\
\hline $\begin{array}{l}\text { Control } \\
\text { (without } \\
\text { fertilizers) }\end{array}$ & 41,6 & - & - & 38,2 & 0,43 \\
\hline Urea & 55,2 & 32,7 & 13,6 & 52,2 & 0,21 \\
\hline Urea with nBPT & 56,4 & 35,6 & 14,8 & 54,8 & 0,16 \\
\hline $\begin{array}{l}\text { Ammonium } \\
\text { nitrate }\end{array}$ & 53,8 & 29,3 & 12,2 & 49,7 & 0,28 \\
\hline $\mathrm{LSD}_{05}$ & 1,3 & - & - & - & - \\
\hline
\end{tabular}

The greatest yield increase in comparison with the control was noted in treatment with application inhibited urea (var.3) $-14.8 \mathrm{t} / \mathrm{ha}$ or $35.6 \%$. It should be mention that although the yield difference between treatments with different forms of urea was not reliable, urea with nBPT had a positive tendency to increase productivity.

We have shown a significant difference between treatment where ammonium nitrate was applied (treatment 4) and treatment with the inhibited urea (treatment 3) $2.6 \mathrm{t} / \mathrm{ha}$ or $5 \%$. It worth to pay special attention to the fact that in treatment with inhibited urea application we have highest yield of marketable potato $-54.8 \mathrm{t} / \mathrm{ha}$. The highest amount of not marketable potato was observed for the control treatment -0.43 $\mathrm{t} / \mathrm{ha}$, and the lowest - for inhibited urea treatment (treatment 3 ) and amounted to 0.16 t/ha (table. 2). 
Evaluating the tubers fractional composition in the variant with the application of inhibited urea (treatment 3 ) we can note that $70 \%$ of tubers is a fraction of $30-60 \mathrm{~mm}$ and $20 \%$ - fraction $>60 \mathrm{~mm}$ (table 3 ).

Table 3. Influence of nitrogen fertilizers forms on potato tuber fractional composition

\begin{tabular}{|c|c|c|c|c|}
\hline \multirow{2}{*}{ Treatments } & \multirow{2}{*}{$\begin{array}{l}\text { Starch content (crude } \\
\text { mass), } \%\end{array}$} & \multicolumn{3}{|c|}{$\begin{array}{c}\text { Tuber fraction composition, } \\
\%\end{array}$} \\
\hline & & 30 mm & $\begin{array}{c}\text { 30-60 } \\
\text { mm }\end{array}$ & $\begin{array}{l}>60 \\
\mathrm{~mm}\end{array}$ \\
\hline $\begin{array}{l}\text { Control } \\
\text { (without fertilizers) }\end{array}$ & 8,14 & 30 & 70 & - \\
\hline Urea & 9,15 & 25 & 65 & 10 \\
\hline Urea with nBPT & 9,22 & 10 & 70 & 20 \\
\hline Ammonium nitrate & 9,05 & 20 & 80 & - \\
\hline $\mathrm{LSD}_{05}$ & 0,34 & - & & - \\
\hline
\end{tabular}

Tuber quality assessment shown that the best results were observed in treatment with inhibited urea (treatment 3), the starch content in the tubers was 9.22\%. Almost the same indicator value was in variant with application conventional urea (treatment 2 ), and the lowest starch content was observed in treatment with ammonium nitrate $9.05 \%$.

Thus, the use of urea with nBPT will provide the yields of potatoes $56,4 \mathrm{t} / \mathrm{ha}$, weight of marketable tubers was $54,82 \mathrm{t} / \mathrm{ha}$, the total yield increase to the control $35,6 \%$. With application of urea with nBPT the lowest yield of non-marketable potato of $0.16 \mathrm{t} / \mathrm{ha}$ was noted, which is 2.65 times less than in the control version. Higher yield and high amount of marketable potato resulted in obtaining higher profit in monetary terms; profit was $42 \%$ higher than in control (the total profit 201500 and 304500 rub per hectare respectively). The more important characteristic is the results of comparison with most often applied fertilizers - urea and ammonium nitrate. The advantage of inhibited urea application in comparison with ammonium nitrate was the increase in the yield of marketable potatoes by $5.1 \mathrm{t} / \mathrm{ha}$ and an additional profit of + 38.25 thousand rubles/ha or $13,3 \%$ was obtained. In comparison with urea additional yield of marketable potato was $2,6 \mathrm{t} / \mathrm{ha}$ and an additional profit of +19.5 thousand rubles/ha or $6,4 \%$.

\section{Product application in commercial condition}

Science 2018 urea with nBPT has been used commercially for potato fertilization, and it's application shown good results.

One commercial trial was conducted in Lipetsk region. Application of ammonium nitrate in dosage $280 \mathrm{~kg} / \mathrm{ha}$ (N90) during the ridge formation was replaced by application of inhibited urea in dosage $210 \mathrm{~kg} / \mathrm{ha}$ (N90). Experimental plot size was 10 hectare. The yield on plot with urea application was 50, 2 t/ha instead 44,4 t/ha on plot with application of ammonium nitrate. Applying urea with nBPT we got more yield and slightly higher amount of marketable potato - 97,3 against $96 \%$. The economic effect of urea with nBPT application was additional income - 32900 $\mathrm{rub} / \mathrm{ha}$.

Another trial was conducted in the condition of west Siberia in Tumen region, Zavoducovskiy settlement, Dronovo village in 2019. During vegetation period there 
was $330,6 \mathrm{~mm}$ precipitation what is $105.6 \mathrm{~mm}$ higher average long-term data. The reserves of available moisture in 1meter soil layer before planting was $148,4 \mathrm{~mm}$, during flowering period $-169,0 \mathrm{~mm}$, in the root layer $-75,2 \mathrm{~mm}$ and $80,9 \mathrm{~mm}$ respectively, what is corresponded to sufficient moisture.

We replaced ammonium nitrate and urea (split application) in potato mineral nutrition system by urea with nBPT (single application). Due to this changes we got $4,7 \%$ higher yield (58,0 t/ha) and higher amount of marketable yield $-88,8 \%$ (instead $80 \%$ on traditional farm technology) (figure 4). Nitrates content were 38,4-46,3 $\mathrm{mg} / \mathrm{kg}$ what is corresponding to normal meanings. Application of urea with nBPT reduced the amount of dry matter by $2.3 \%$ and amounted to $17.8 \%$, but the same time increased the starch content in potato tubers by $5.2 \%-15.8 \mathrm{mg} / \mathrm{kg}$ relative to the control.

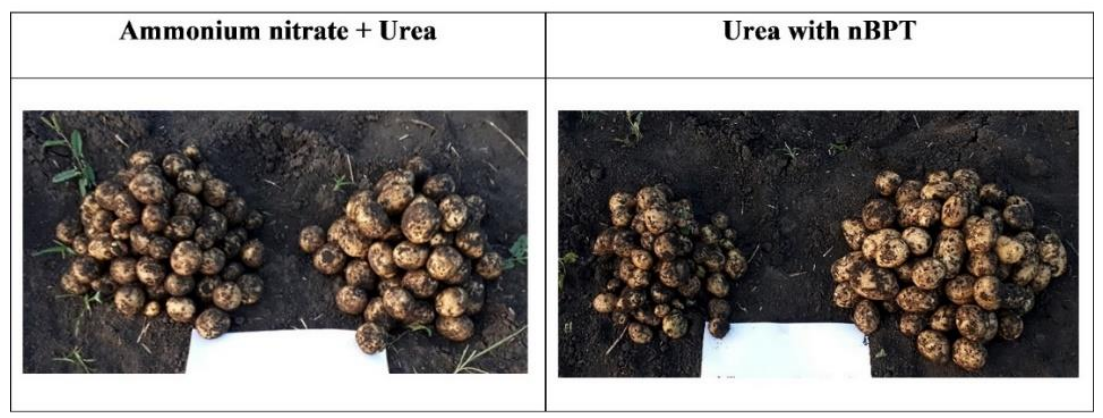

Fig. 4. The result of application Urea with nBPT (on the right side of photo- marketable yield)

The introduction of urea with nBPT into the mineral nutrition system at a dose of $100 \mathrm{~kg}$ / ha before row forming increased the fertilizers cost up to 23,170. 0 rubles/ha, which is higher than the control by 6862.83 rubles / ha. However, this system increased the yield by $4.0 \mathrm{t} / \mathrm{ha}$, and profitability $12.3 \%$, and allowed to get additional income - $33000 \mathrm{rub} / \mathrm{ha}$.

\section{Conclusion}

As a result of the research it was found that the use of urea with the nBPT inhibitor allows to obtain a number of advantages both in potato growing systems. The use of urea with urease inhibitor (in institution trial) allowed to increase potato yield by $3.4 \mathrm{t} / \mathrm{ha}$, and yield of marketable fraction by $5.1 \mathrm{t} / \mathrm{ha}$ in comparison with the variant with the use of ammonium nitrate. Additional income amounted to more than 38 thousand rubles. Commercial trials shown the same tendency, application of urea with urease inhibitor allows to get higher yield $(5,8-4,0$ t/ha depending on region), higher amount of marketable yield $(88-97 \%)$ and additional income 32000 - $33000 \mathrm{rub} / \mathrm{ha}$.

\section{References}


1. L. Sheo, B. Upadhaya, Urease inhibitors: a review. Indian Jurnal of biotechnology 11, 381-388 (2012)

2. H. Cantarella, R. Otto, J.R. Soares, G.B. Aijânio, Silva Agronomic efficiency of NBPT as a urease inhibitor: A review. Jurnal of Advanced research 13, 19-27 (2018)

3. IFA International Fertilizer Association. 2017a. Fertilizer outlook 2017-2021. IFA annual conference - 22-24 May 2017 Marrakech (Marocco). Paris: IFA International Fertilizer Association, Services PITaA.

4. IFA International Fertilizer Association. 2017b. Short-term fertilizer outlook 2017- 2018 report. Paris: IFA International Fertilizer Association, Services PITaA.

5. S. Bittman, M. Dedina, C.M. Howard, O. Oenema, M.A. Sutton, Options for ammonia mitigation: guidance from the UNECE Task Force on Reactive Nitrogen. Edinburgh: Centre for Ecology and Hydrology (CEH) (2014)

6. A. Delgado, M. Quemada, F.J. Villalobos, Fertilizers. Principles of Agronomy for Sustainable Agriculture. Springer, Cham (2016) https://doi.org/10.1007/9783-319-46116-8_23

7. J. Zheng, M.M. Kilasara, W.N. Mmari, et al., Ammonia volatilization following urea application at maize fields in the East African highlands with different soil properties. Biol Fertil Soils 54, 411-422 (2018) https://doi.org/10.1007/s00374018-1270-0

8. M.A. Sutton, A. Bleeker, C.M. Howard, M. Bekunda, B. Grizzetti, de Vries W, et al., Our Nutrient World: the challenge to produce more food and energy with less pollution. Edinburgh: Centre for Ecology and Hydrology (2013)

9. X. Liu, L. Chen, Z. Hua, et al., Comparing ammonia volatilization between conventional and slow-release nitrogen fertilizers in paddy fields in the Taihu Lake region. Environ Sci Pollut Res 27, 8386-8394 (2020) https://doi.org/10.1007/s11356-019-07536-2

10. Q. Yang, P. Liu, S. Dong, et al., Combined application of organic and inorganic fertilizers mitigates ammonia and nitrous oxide emissions in a maize field. Nutr Cycl Agroecosyst 117, 13-27 (2020) https://doi.org/10.1007/s10705-020-100602

11. Z. N. Markina, Basics of agricultural chemistry Teaching manual, 121 (Bryansk, BGITA, 2012)

12. C. Tian, X. Zhou, Z. Ding, et al., Controlled-release $\mathrm{N}$ fertilizer to mitigate ammonia volatilization from double-cropping rice. Nutr Cycl Agroecosyst 119, 123-137 (2021) https://doi.org/10.1007/s10705-020-10108-3

13. N. Yahya, Urea Fertilizer: The Global Challenges and Their Impact to Our Sustainability. In: Green Urea. Green Energy and Technology. Springer, Singapore (2018) https://doi.org/10.1007/978-981-10-7578-0_1

14. C. Guo, T. Ren, P. Li, et al., Producing more grain yield of rice with less ammonia volatilization and greenhouse gases emission using slow/controlled-release urea . Environ Sci Pollut Res 26, 2569-2579

(2019) https://doi.org/10.1007/s11356-018-3792-2 
15. T. Mannheim, N. Bereger, Fertilization of crops with stabilized nitrogen fertilizers//international agricultural journal "Scientific support and management of agro-industrial complex" 3, 28-30 (2015)

16. R. Engel, C. Romero, K. Jones, T. Jensen, The Loss of ammonia and the use of nitrogen by plants from urea at a superficial introduction in the winter months, Food plants 3, 13-16 (2018) 